\title{
UPAYA MENINGKATKAN KEMAMPUAN SISWA PADA KOMPETENSI MELAYANI MAKAN DAN MINUM DI RESTORAN MATA PELAJARAN \\ TATA HIDANG DENGAN MENGGUNAKAN MODEL PEMBELAJARAN THINK PAIR SHARE DI KELAS XI TATA BOGA 2 SMK NEGERI 8 MEDAN TAHUN AJARAN $2014-2015$
}

\author{
Ngatmini \\ Guru SMK Negeri 8 Medan Program Keahlian Tata Boga \\ Email: mini_ngatmini@yahoo.co.id
}

\begin{abstract}
ABSTRAK
Penelitian ini merupakan penelitian tindakan kelas yang bertujuan untuk Meningkatkan Kemampuan Siswa pada Kompetensi Melayani Makan dan Minum di Restoran, Mata Pelajaran Tata Hidang dengan menggunakan Model Pembelajaran Think Pair Share (TPS) di Kelas XI Tata Boga 2 SMK Negeri 8 Medan Tahun Ajaran 2014 - 2015. Tata Hidang merupakan salah satu mata pelajaran pada paket keahlian Tata Boga. Melalui penerapan model pembelajaran Think Pair Share, diharapkan dapak meningkatkan kemampuan siswa pada kompetensi dasar Melayani Makan dan Minum di Restoran di kelas XI Tata Boga 2 . Metode penelitian tindakan kelas ini dilaksanakan dalam 2 siklus, dimana dalam setiap 1 siklus dilaksanakan dalam 2 pertemuan dan pada setiap siklus diselesaikan melalui tahap perencanaan, tahap pelaksanaan tindakan, tahap pengamatan, dan tahap refleksi. Subjek pada penelitian ini adalah siswa kelas XI Tata Boga 2 SMK Negeri 8 Medan terdiri dari 32 orang. Pengumpulan data yang digunakan dalam penelitian ini adalah observasi. Hasil penelitian menunjukkan bahwa penerapan model pembelajaran Think Pair Share dapat meningkatkan kemampuan dasar melayani makan dan minum di restoran, mata pelajaran Tata Hidang pada siswa kelas Kelas XI Tata Boga 2, SMK Negeri 8 Medan. Hal tersebut dapat dilihat dari pencapaian persentase ketuntasan belajar yakni pada siklus I pertemuan I mencapai $23,3 \%$ siswa yang tuntas,dan76,7\% tidak tuntas. Siklus I pertemuan II terdapat $62,86 \%$ siswa yang tuntas dan $37,14 \%$ siswa yang tidak tuntas. Pada siklus II pertemuan I terdapat $77,14 \%$ siswa yang tuntas dan $22,86 \%$ siswa yang tidak tuntas sedangkan pada siklus II pertemuan II meningkat menjadi $100 \%$ atau 32 orang siswa yang tuntas.
\end{abstract}

Kata Kunci : Model Pembelajaran, Think Pair Share, Kompetensi

\section{PENDAHULUAN}

Berdasarkan Kurikulum 2013

khususnya Kompetensi dasar Melayani Makan dan Minum di Restoran berorientasi pada hakikat pembelajaran praktik yang berorientasi pada pelayanan Makan dan Minum tamu di restoran. Pada kompetensi Melayani Makan dan Minum di Restoran, siswa diharapkan mampu menangani prosedur pelaksanaan Melayani Makan dan Minum di Restoran, dimana guru berperan sebagai tamu.

Prosedur yang harus dilakukan siswa mulai menyambut tamu, mempersilahkan tamu duduk, menawarkan menu pada tamu, taking order, melayani Makan dan Minum , crumbing down sampai pada pemberian bill danmenghantar tamu keluar dari restoran. Dalam proses melayani pesanan Makan dan Minum di restoran, penulis memfokuskan pada Standar Operational Procedur (SOP) atau prosedur pelaksanaan dasar merupakan suatu ketetapan yang terstandar untuk mempertahankan kualitas dan hasil pekerjaan. Dampak SOP dalam Food \& Beverage Departement merupkan suatu hal yang sangat memudahkan pekerjaan waiter danmenciptakan suasana yang membuat para tamu menjadi nyaman danmendapatkan kepuasan dalam pelayanan Makan dan Minum. 
Berdasarkan pengalaman di lapangan (empiris) diketahui bahwa kemampuan melayani pesanan Makan dan Minum di restoran siswa kelas Kelas XI Tata Boga 2 SMK Negeri 8 Medan dalam proses pembelajaran masih belum optimal. Dari data yang ada menunjukkan dari hasil perolehan nilai tersebut dari jumlah 32 orang siswa, hanya $34,37 \%$ (11 siswa) yang mendapat nilai 75 keatas ( kriteria ketuntasan minimal), sedangkan 65,625\% (21 siswa) mendapat nilai dibawah 75 . Selain itu, dari tugas sebelumnya yang diberikan oleh guru kurang menampakkan adanya peningkatan kemampuan Melayani Makan dan Minum di Restoran.

Bedasarkan latar belakang, maka peneliti mencoba membuat penelitian melalui penelitian tindakan kelas dengan judul “ Upaya Meningkatkan Kemampuan Siswa pada Kompetensi Dasar Melayani Makan dan Minum di Restoran dengan Menggunakan Model Pembelajaran Think Pair Share (TPS) di kelas Kelas XI Tata Boga 2 SMK Negeri 8 Medan Tahun Ajaran 2014 - 2015”.

\section{KAJIAN TEORITIS}

Pengertian Kemapuan adalah suatu kecakapan atau potensi yang dimiliki oleh seseorang untuk melakukan suatu tindakan. Kemampuan menunjukan bahwa suatu tindakan dapat dilaksanakan sekarang. Menurut Chaplin (2009) ability ( kemampuan, kecakapan, ketangkasan, bakat, kesanggupan) merupakan tenaga (daya kekuatan) untuk melakukan suatu perbuatan. Selanjutnya Robbins (2008) mengatakan, kemampuan bisa merupakan kesanggupan bawaan sejak lahir, atau merupakan hasil latihan atau praktek.

Menurut Marsum (1994:7) restoran adalah "suatu tempat atau bangunan yang diorganisasi secara komersial, yang menyelenggarakan pelayanan dengan baik kepada semua tamunya baik berupa makan maupun minum”. Selanjutnya Endar Sugiarto (1996:7) mengatakan bahwa Restoran adalah suatu tempat yang identik dengan jajaran meja - meja yang tersusun rapi, dengan kehadiran orang, timbulnya aroma semerbak dari dapur danpelayanan para pramusaji, berdentingnya bunyi-bunyian kecil karena persentuhan gelas - gelas kaca, porselin, menyebabkan suasana hidup di dalamnya".

Model pembelajaran pada dasarnya merupakan bentuk pembelajaran yang tergambar dari awal sampai akhir yang disajikan secara khas oleh guru (Slavin dalam Komalasari, 2011: 57). Soekamto, dkk., (dalam Trianto, 2010: 22) mengemukakan model pembelajaran adalah kerangka konseptual yang melukiskan prosedur yang sistematis dalam mengorganisasikan pengalaman belajar untuk mencapai tujuan belajar tertentu, dan berfungsi sebagai pedoman bagi para perancang pembelajaran.

Pembelajaran kooperatif adalah suatu model pembelajaran yang saat ini banyak digunakan untuk mewujudkan kegiatan pembelajaran yang berpusat pada siswa (student centered) terutama untuk mengatasi permasalahan guru dalam mengaktifkan siswa, yang tidak dapat bekerjasama dengan orang lain (Isjoni, 2007: 16). Pembelajaran kooperatif merupakan pembelajaran yang merujuk pada berbagai metode pengajaran dimana para siswa bekerja dalam kelompok-kelompok kecil untuk saling membantu satu sama lainnya dalam mempelajari materi pembelajaran (Slavin, 2010: 4). Pembelajaran kooperatif adalah suatu strategi pembelajaran di mana siswa belajar dan bekerja dalam kelompok-kelompok kecil secara kolaboratif yang anggotanya terdiri dari 2-5 orang, struktur kelompoknya yang bersifat heterogen (Slavin dalam Komalasari, 2011: 62).

Arends (dalam Komalasari, 2011: 64) menyatakan bahwa Think Pair Share merupakan suatu cara yang efektif untuk membuat variasi suasana pola diskusi kelas. Sejalan dengan itu, menurut Trianto (2010: 81) mengemukakan bahwa model pembelajaran Think Pair Share (TPS) atau berpikir-berpasangan-berbagi merupakan jenis pembelajaran kooperatif yang dirancang untuk mempengaruhi pola interaksi siswa.

Menurut Muslimin (2009) langkahlangkahThink Pair Share ada tiga, yaitu: Thinking (berpikir), siswa diberi pertanyaan dan harus memikirkan jawaban secara individu.Pairing (berpasangan), siswa dengan 
teman sebangku mendiskusikan yang telah dipikirkan pada tahap thinking, dan Sharing (berbagi), siswa berpasangan berbagi hasil diskusi kepada seluruh kelompok.

Pelaksanaan pembelajaran menggunakan model pembelajaran kooperatif tipe Think Pair Share (TPS) pada penelitian ini menggunakan langkah-langkah seperti tersebut di atas. Ppenyesuaian pada siswa kelas XI Tata Boga 2 yang menjadi kelas penelitian. Berikut langkah-langkahnya yaitu: (1) Think, guru membimbing siswa saat mencari masukan jawaban atau pendapat yang bersumber dari buku yang relevan secara individu atas pertanyaan yang diberikan kepada siswa, (2) Pair, mengembangkan aktivitas berpikir siswa dalam berdiskusi jawaban satu sama lain dengan teman sebangku, dan mengupayakan siswa aktif dalam diskusi dengan teman sebangku di belakang/ di depannya atau dalam kelompok (kelompok terbentuk), dan (3) Share, membimbing aktivitas penyajian hasil diskusi masing-masing kelompok yang ditanggapi oleh kelompok lain.

\section{METODOLOGI PENELITIAN}

Penelitian ini dilaksanakan di SMK Negeri 8 Medan tahun 2015. Subjek penelitian ini adalah siswa kelas Kelas XI Tata Boga 2 , Tahun Ajaran 2014 - 2015 sebanyak 1 kelas dengan jumlah siswa 32 orang.

Objek penelitian ini adalah Penelitian Tindakan Kelas dengan menggunakan model pembelajaran Think Pair Share sebagai sasaran utama. Penelitian ini berusaha memaparkan upaya meningkatkan kemampuan siswa pada kompetensi Melayani Makan dan Minum di Restoran melalui model pembelajaran Think Pair Share. Prosedur pelaksanaan penelitian tindakan kelas ini memiliki alur sebagaimana gambar 1 di bawah ini menurut Arikunto (2008:16).

Analisis data adalah proses mencari dan menyususn secara sistematis data yang diperoleh dari hasil penelitian pada 2 siklus. Proses dilakukan dengan mencari dan menyususn secara sistematis data yang diperoleh dari hasil wawancara, catatan lapangan dan dokumentasi dengan cara mengorganisasikan data ke dalam kategori, menjabarkan ke dalam unitunit, melakukan sintesa, menyusun ke dalam pola, memilih mana yang penting dan yang akan dipelajari dan membuat kesimpulan sehingga mudah dipahami oleh diri sendiri maupun orang lain, teknik analisis data dilakukan dengan melalui tiga tahap, yaitu mereduksi data, pemaparan data, dan menyimpulkan.

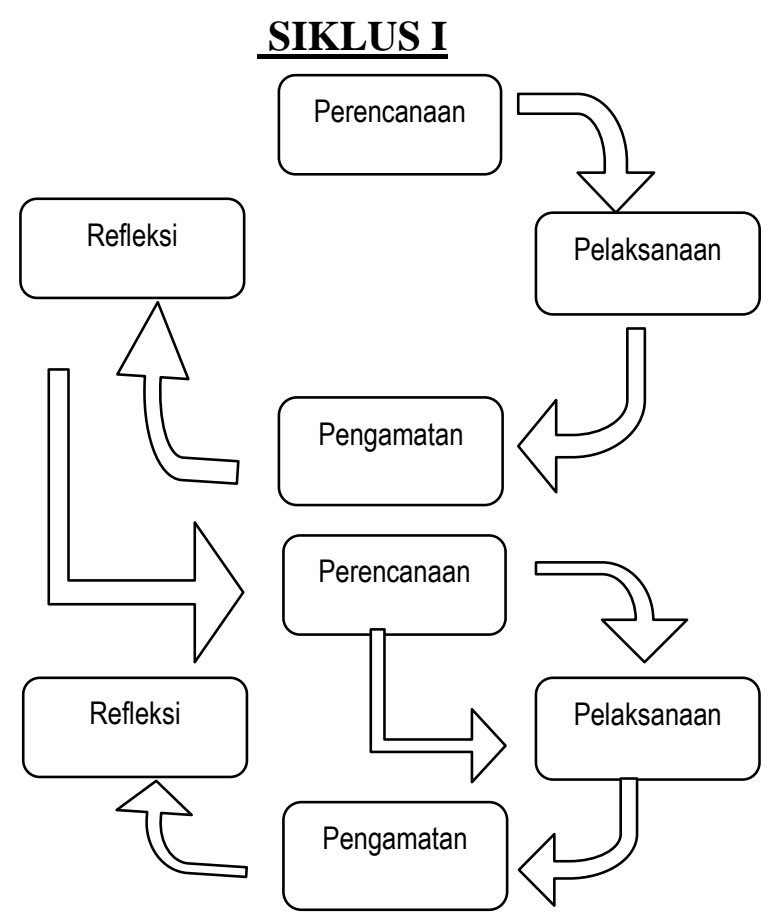

\section{Gambar 1 : Model Penelitian Tindakan Kelas}

Untuk mengetahui tingkat kemampuan siswa terhadap materi yang telah diajarkan dalam kegiatan pembelajaran yaitu ketuntasan kompetensi siswa, tercermin pada skor mentah yang dicapai dan pedoman konversi yang umum digunakan.

Tabel 1 Kriteria Tingka Keberhasilan Siswa Dalam \%

\begin{tabular}{|c|c|}
\hline Rentang Nilai (\%) & Kriteria \\
\hline $85 \%-100 \%$ & Sangat Baik \\
\hline $70 \%-84 \%$ & Baik \\
\hline $55 \%-69 \%$ & Cukup \\
\hline $0 \%-54 \%$ & Kurang \\
\hline & \\
\hline
\end{tabular}

Sumber : Suharsimi Arikunto (2010:134)

Upaya Meningkatkan Kemampuan Siswa Pada Kompetensi Melayani Makan dan Minum di

Restoran Mata Pelajaran Tata Hidang dengan Menggunakan Model Pembelajaran Think Pair - 
Berdasarkan pedoman skala pada tabel diatas maka kriteria keterapaian tingkat kemampuan siswa adalah paling sedikit skor siswa mencapai kategori cukup. Tingkat penguasaan kemampuan siswa pada kompetensi Melayani Makan dan Minum di Restoran secara individu berdasarkan observasi dapat digunakan rumus sebagai berikut:

$\mathrm{Pi}=\frac{f}{n} \times 100$ ( Sudjana, 2009: 133)

$\mathrm{Pi}=$ persentase hasil pengamatan

$\mathrm{f}=$ jumlah skor hasil observasi

$\mathrm{n}=$ jumlah skor maksimal

Untuk menghitung hasil belajar Tata

Hidang pada kompetensi Melayani Makan dan Minum di Restoran telah meningkat atau tidak, dapat dilihat dari hasil tes yang mereka

peroleh dari setiap siklusnya. Dimana setiap skor masing-masing tes yang diberikan akan

dilihat ketuntasannya secara klasikal dengan menggunakan persamaan :

Dimana"

$$
\mathrm{P}=\frac{f}{n} \times 100 \%
$$

$$
\begin{aligned}
& \mathrm{P}=\text { jumlah persentase siswa yang } \\
& \text { mengalami perubahan } \\
& \mathrm{f}=\text { jumlah siswa yang tuntas } \\
& \mathrm{n}=\text { jumlah siswa keseluruhan }
\end{aligned}
$$

\section{HASIL DAN PEMBAHASAN}

\section{Hasil Penelitian}

Penelitian ini berbentuk Penelitian Tindakan Kelas yang dilakukan di SMK Negeri 8 Medan di kelas Kelas XI Tata Boga 2. Di mana pembelajaran ini dilaksanakan menggunakan model pembelajaran Think Pair Share untuk meningkatkan keterampilan Melayani Makan dan Minum di Restoran dalam proses belajar mengajar. Penelitian ini terdiri dari dua siklus, dimana siklus pertama dilaksanakan dalam dua kali pertemuan dan siklus kedua juga dilaksanakan dalam dua kali pertemuan. Setiap siklus diakhiri dengan memberikan postes dari palajaran yang diberikan, kemudian pembuatan laporan berdasarkan hasil penelitian Pada siklus II pertemuan I terdapat $77,14 \%$ siswa yang tuntas dan $22,86 \%$ siswa yang tidak tuntas sedangkan pada siklus II pertemuan yang ke II meningkat menjadi $100 \%$ atau 32 orang siswa yang tuntas.

\section{Pembahasan Penelitian}

Setelah melakukan penelitian sebanyak 2 siklus ( 4 x pertemuan ) dapat disimpulkan bahwa penerapan Think Pair Share (TPS) pada pelajaran Melayani Makan dan Minum di Restoran baik secara individual maupun secara klasikal, hal ini juga dapat dilihat dari hasil data rekapitulasi mulai dari siklus I sampai dengan siklus II.

Dari data pada tabel rekapitulasi dapat diketahui bahwa rata rata skor peningkatan kemampuan Melayani Makan dan Minum di Restoran siswa secara individual terus meningkat selama 2 siklus (4 pertemuan) pada siklus I pertemuan I, persentase rata rata nilai tingkat kemampuan Melayani Makan dan Minum di Restoran adalah 73,26\% (cukup). Pada siklus I pertemuan ke II persentase rata rata nilai tingkat kemampuanMelayani Makan dan Minum di Restoran adalah 78,28\% (baik).Pada siklus ke II pertemuan I persentase rata rata nilai tingkat kemampuan Melayani Makan dan Minum di Restoran adalah 79,69\% (baik).Pada siklus ke II pertemuan ke II mengalami peningkatan rata rata nilai tingkat kemampuan Melayani Makan dan Minum di Restoran adalah 81,71\% ( baik ). Pelaksanaan penelitian ini telah dilaksanakan dengan sebaik mungkin dengan menggunakan prosedur metode ilmiah, akan tetapi apapun metode yang digunakan tidak tertutup kemungkinan ada kekeliruan dalam penelitian, maupun kesalahan dan kelemahan. Dari variable hasil belajar siswa diperoleh dengan menggunakan tes praktik yang diberikan terhadap responden terpilih.

\section{Analisis Peningkatan pembelajaran Siklus I dan Siklus II}

Berdasarkan data hasil belajar yang diperoleh dari hasil penelitian, dapat dianalisis perbandingan hasil belajar untuk setiap siklusnya terdapat peningkatan kemampuan siswa dengan penerapan model pembelajaran Think Pair Share, seperti yang dirinci pada tabel berikut : 
Tabel 2 data Hasil Belajar pada Siklus I

\begin{tabular}{|c|c|c|c|c|c|}
\hline \multirow{2}{*}{ No } & \multirow{2}{*}{$\begin{array}{c}\text { Tingkat } \\
\text { Ketuntasan }\end{array}$} & \multicolumn{2}{|c|}{$\begin{array}{c}\text { Siklus I } \\
\text { Pertemuan I }\end{array}$} & \multicolumn{2}{c|}{$\begin{array}{c}\text { Siklus I } \\
\text { Pertemuan II }\end{array}$} \\
\cline { 3 - 6 } 1 & Jlh & $\%$ & Jlh & $\%$ \\
\hline \multirow{2}{*}{2} & $\begin{array}{c}\text { Tuntas } \\
75 \%\end{array}$ & 8 & 23,3 & 22 & 62.86 \\
\hline $\begin{array}{c}\text { Tidak } \\
\text { Tuntas } \leq \\
75 \%\end{array}$ & 24 & 76,7 & 10 & 37.14 \\
\hline \multicolumn{2}{|c|}{ Jumlah } & 32 & 100 & 32 & 100 \\
\hline
\end{tabular}

Tabel 3 data Hasil Belajar pada Siklus II

\begin{tabular}{|c|c|c|c|c|c|}
\hline \multirow{2}{*}{ No } & \multirow{2}{*}{$\begin{array}{c}\text { Tingkat } \\
\text { Ketuntasan }\end{array}$} & \multicolumn{2}{|c|}{$\begin{array}{c}\text { Siklus II } \\
\text { Pertemuan I }\end{array}$} & \multicolumn{2}{|c|}{$\begin{array}{c}\text { Siklus II } \\
\text { Pertemuan II }\end{array}$} \\
\cline { 3 - 6 } 1 & Jlh & $\%$ & Jlh & $\%$ \\
\hline & $\begin{array}{c}\text { Tuntas } \\
75 \%\end{array}$ & 24 & 77.14 & 32 & 100 \\
\hline 2 & $\begin{array}{c}\text { Tidak } \\
\text { Tuntas } \leq \\
75 \%\end{array}$ & 8 & 22.86 & 0 & 0 \\
\hline & Jumlah & 32 & 100 & 32 & 100 \\
\hline
\end{tabular}

\section{KESIMPULAN}

Dari hasil pembahasan yang Telah dikemukakan pada bab-bab sebelumnya serta analisis yang telah ada, maka peneliti peroleh kesimpulan sebagai berikut: (1) Penggunaan Model Pembelajaran Think Pair Share (TPS) dapat meningkatkan ketrampilan siswa pada pelajaran Menerima dan mencatat reservasi di kelas Kelas XI Tata Boga 2 SMK Negeri 8 MedanTahun Ajaran 2014-2015 dan (2) Penelitian dibagi menjadi II siklus, setiap siklus terdiri dari $2 \times$ pertemuan, peneliti menggunakan analisis data observasi.

Hasil penelitian berdasarkan observasi yang dilakukan oleh guru: rata-rata skor peningkatan kemampuan Melayani Makan dan Minum di Restoran siswa secara individual terus meningkat selama 2 siklus ( 4 pertemuan ) Pada siklus I pertemuan I, persentase rata - rata tingkat kemampuan Melayani Makan dan Minum di Restoran adalah 63,4\% (kurang). Pada siklus I pertemuan ke II persentase rata - rata nilai kemampuan Melayani Makan dan Minum di Restoran siswa adalah 34,29\% ( cukup ) dan pada siklus ke II pertemuan I persentase rata
- rata nilai kemampuan Melayani Makan dan Minum di Restoran siswa adalah 57,14\% ( baik ) danpada siklus ke II pertemuan ke II mengalami peningkatan rata rata nilai tingkat kemampuan Melayani Makan dan Minum di Restoran siswa mencapai $80 \%$ ( Baik).

\section{DAFTAR PUSTAKA}

Chaplin,J.P.2009.Kamus Lengkap Psikologi. Jakarta: Raja Grafindo.

Endar Sugiarto, Sri Sulastriningrum.2002. Restoran dan Segala Permasalahannya. Yogyakarta: Andi Nasution.

Isjoni. 2010. Cooperative Learning. Alfabeta. Bandung.

Komalasari.2011. Pembelajaran Kontekstual Konsep dan Aplikasi. Bandung: Refika Aditama.

Marsum.WA, 1994. Restoran dan Segala Permasalahannya, Jogjakarta : Andi Offset.

Muslimin, Ibrahim. 2005. Penelitian Eksperimen Dalam Pendidikan. Surabaya: UNESA University Press.

Nana Sudjana.2009. Penilaian Hasil Proses Belajar Mengajar. Bandung: PT Remaja Rosdakarya.

Riyanto, Yatim. 2010. Paragigma Baru Pembelajaran: Sebagai Referensi bagi Guru/Peneliti dalam Implementasi Pembealajran yang Efektif dan Berkualitas. Jakarta: Kencana

Suharsimi Arikunto. 2010. Prosedur Penelitian Suatu Pendekatan Praktik Jakarta; Rineka Cipta.

Slavin E. Robert. 2005.Cooperatif Learning: Teori, Riset, dan Praktik. Bandung: Nusa Media.

Trianto, 2009. Mendesain Model Pembelajaran Inovatif- Progresif. Jakarta : Kencana

Wiwoho, A. 2008. Pengetahuan Tata Hidang. Jakarta : Erlangga

Zainal. 2009. Penelitian Tindakan Kelas untuk Guru SMP, SMA, SMK. Bandung: Yrama Widi. 
